\title{
Discontinuity in Growth Potential of Jack Pine in Ontario: A 20-Year Provenance Assessment
}

\author{
D. A. Skeates, \\ Ontario Forest Research Centre \\ Ontario Ministry of Natural Resources \\ Maple, Ontario LOJ 1EO
}

\begin{abstract}
The province of Ontario is divided into three major jack pine populations as a result of grouping 12 seed sources on the basis of growth characteristics, 20 years from sowing. Migration following glaciation is postulated as a cause of population differentiation.

Growth of trees from the 12 stands was positively but weakly correlated with growing degree days. However some northern sources flourished in southern plantations. Consistent growth differences were found between some geographically close sources, justifying further, more intensive sampling to identify the most productive sources of seed for each of the major areas of jack pine silvicultural activity in the province.
\end{abstract}

\section{Résumé}

La province ontarienne est divisée en trois grandes populations de pin gris à la suite d'un essai de 12 provenances classées après 20 ans de plantation suivant les critères de croissance. On pose I'hypothèse des phénomènes de la migration, postérieure à la glaciation comme cause principale des différences entre populations.

La croissance des arbres issue des 12 peuplements-mères était positivement bien que faiblement correlée aux degrés-jours de croissance. Cependant, quelques populations septentrionales fournirent de bon rendement dans les plantations méridionales. L'existence de différences permanentes entre des populations d'origine géographiquement rapprochées justifient la poursuite d'un échantillonnage plus intensif afin d'identifier les familles les plus prometteuses pour chaque grande population de pin gris dans la province.

\section{Introduction}

This study was undertaken to determine whether there is significant variation in potential growth amongst jack pine (Pinus banksiana Lamb.) seed sources and if so, how such variation could be used to increase productivity ${ }^{1}$. Any gains in productivity could apply to the 12 to 16000 ha of the jack pine working group being regenerated annually in Ontario.

Since the productive forest land base is steadily decreasing as land is allocated to other uses, increased productivity is essential simply to maintain the current forest harvest. Yeatman (1974) has suggested that estimated gains in growth of $10 \%$ are likely from wise application of provenance information. Gains in productivity of this magnitude would be equivalent to an additional 12 to 1600 ha regenerated annually without the associated cost of site preparation and planting or seeding.

\section{Procedures}

Seed from 12 natural stands in Ontario (Fig. 1) was sown in the Ministry of Natural Resources nursery at Midhurst, Ontario and shipped as $2+1$ transplants. Stock was planted in 1955 in two experiments on typical jack pine sites in site regions $4 \mathrm{E}$ and $5 \mathrm{E}$ (Hills 1960), Cane Township of the Kirkland Lake forest district and Maria Township, Algonquin Park District respectively. Each planting included all 12 seed sources in four replications of 400 tree plots.

1Carmichael, A. J., 1958 - Unpublished project outline.
In order to extend the scope of the study, the remaining seed of the same seed lots was sown producing smaller quantities of a reduced number of sources. These were shipped from Midhurst in 1957 for experiments in site regions $3 E$ and $6 E$, established in German Township of the Timmins forest district and West Gwillimbury Township of Huronia District. In the former, nine sources were planted in three replications of 36 tree plots and in the latter six sources in four replications of 49 trees.

All stock was machine-planted in furrows at 2-m spacing using a standard Lowther tree planter. Locations of sources and planting sites are shown in Fig. 1.

In the first assessment, heights of ten trees per plot were measured at 10 years from seed in the two 1955 plantations (Carmichael 1962). In 1971 heights and diameters were measured in all four experiments. In the 1957 plantings measurements at 18 years from sowing were taken on all trees while in the 1955 plantings, at 20 years from seed, a central plot of 100 trees was assessed. Sampling modification was necessary for portions of the two larger experiments due to plantation irregularity and survival variability. Volumes were estimated from published tables (Honer 1967).

Variance was analyzed for 1961 heights in Cane and Maria Townships and 1971 heights, diameters and volumes for each of the four experiments. Height data from the 1961 and 1971 measurements in Cane and Maria Townships were pooled in a factorial analysis of variance to assess interactions between years, experimental sites, sources and replications. Since none of the interactions were significant, multiple height, volume and diameter comparisons between sources were made according to established procedures (Snedecor and Cochran 1967) using combined 1971 data for the two 1955 experiments.

A correlation between height data and growing degree days above $42^{\circ} \mathrm{F}$ (Boughner and Kendall 1959) was analyzed.

\section{Results}

Although site, design and restricted numbers of sources limit the interpretation of the two 1957 experiments, all trials have been included to illustrate the similarity of growth patterns of the various seed lots (Fig. 2). Height differences between sources were not statistically significant in the 1957 experiments. Diameter and volume differences were marginally significant $(p=.10)$ in West Gwillimbury but not in German Township.

Height differences in 1971 in the 1955 trials were highly significant $(p=.001)$. Diameter differences were not statistically different, but volumes were statistically different in Maria Township $(p-.05)$ and marginally so in Cane Township $(p=.10)$. Analyses of variance for pooled 1971 data from these two experiments suggested that for young plantations, height was the most valuable indicator of provenance variation (Table 1).

Factorial analysis of height data in Cane and Maria Townships for the two dates of measurement indicated no significant interactions. Therefore the performance of the 
12 sources was similar at the two sites and consistent over the 10-year period, suggesting that reasonable confidence may be placed in early results as was found by Yeatman (1974). However, the results presented here are based primarily on assessment of 1971 height data from the two large complete trials in Cane and Maria Townships.

Data (Table 1) appear to group naturally into geographic areas. Sources from northwestern and northeastern Ontario were $11 \%$ taller than Pickle Lake, Geraldton, Mobert and Franz in north-central Ontario. Trees of Pickle Lake origin were significantly shorter than all other sources except those of the north-central group. Trees of Kab Lake and
Sioux Loskout origins, though geographically closer to Pickle Lake than are Geraldton, Franz or Mobert, outperformed Pickle Lake trees (Fig. 3). Geraldton trees were considerably shorter than those from Kab Lake though not significantly so at the $95 \%$ level. Performance of Franz and Mobert trees was similar in absolute terms to those from Geraldton but not statistically different from those from Kab Lake or Hardwick to the west or Connaught to the east. Franz and Mobert are near the southern extreme of the north-central group.

Heights in 1971 varied somewhat with length of growing season at origin of seed in terms of degree days above $42^{\circ} \mathrm{F}$

Table 1. Mean heights, diameters and volumes from pooled 1971 data, Cane and Maria Twps

\begin{tabular}{|c|c|c|c|c|c|c|c|c|}
\hline \multirow{2}{*}{ Seed source } & \multicolumn{2}{|c|}{ Height } & & \multicolumn{2}{|c|}{ Diameter } & \multicolumn{2}{|c|}{ Volume } & \\
\hline & (ft.) & (cm) & & (in.) & (cm) & $\left(\mathrm{ft}^{3}{ }^{3}\right)$ & $\left(\mathrm{dm}^{3}\right)$ & \\
\hline Markstay & 23.31 & 7.10 & $a^{*}$ & 3.47 & 8.81 & .8020 & 22.71 & a \\
\hline Sioux Lookout & 22.68 & 6.91 & $a b$ & 3.40 & 8.64 & .7299 & 20.67 & $a b c$ \\
\hline Timmins & 22.52 & 6.86 & $a b$ & 3.37 & 8.56 & .7611 & 21.55 & $a b$ \\
\hline Goldie & 21.98 & 6.70 & $a b c$ & 3.34 & 8.48 & .6874 & 19.47 & $a b c$ \\
\hline Algoma & 21.75 & 6.63 & $\mathrm{bc}$ & 3.38 & 8.59 & .6954 & 19.69 & $a b c$ \\
\hline Hardwick & 21.32 & 6.50 & $\mathrm{~cd}$ & 3.32 & 8.43 & .6766 & 19.16 & $a b c$ \\
\hline Connaught & 21.20 & 6.46 & $\mathrm{~cd}$ & 3.29 & 8.36 & .6595 & 18.68 & $a b c$ \\
\hline Kab Lake & 20.97 & 6.39 & cde & 3.30 & 8.38 & .6815 & 19.30 & $a b c$ \\
\hline Mobert & 20.27 & 6.18 & def & 3.28 & 8.33 & .6414 & 18.16 & $a b c$ \\
\hline Franz & 20.09 & 6.12 & def & 3.22 & 8.18 & .6057 & 17.15 & bc \\
\hline Geraldton & 19.75 & 6.02 & ef & 3.20 & 8.13 & .6122 & 17.34 & bc \\
\hline Pickle Lake & 18.93 & 5.77 & $f$ & 3.24 & 8.23 & .5810 & 16.45 & c \\
\hline
\end{tabular}

*Snedecor and Cochran, 1967. Studentized range test.

Data followed by the same letter do not vary significantly at the $95 \%$ level of probability.

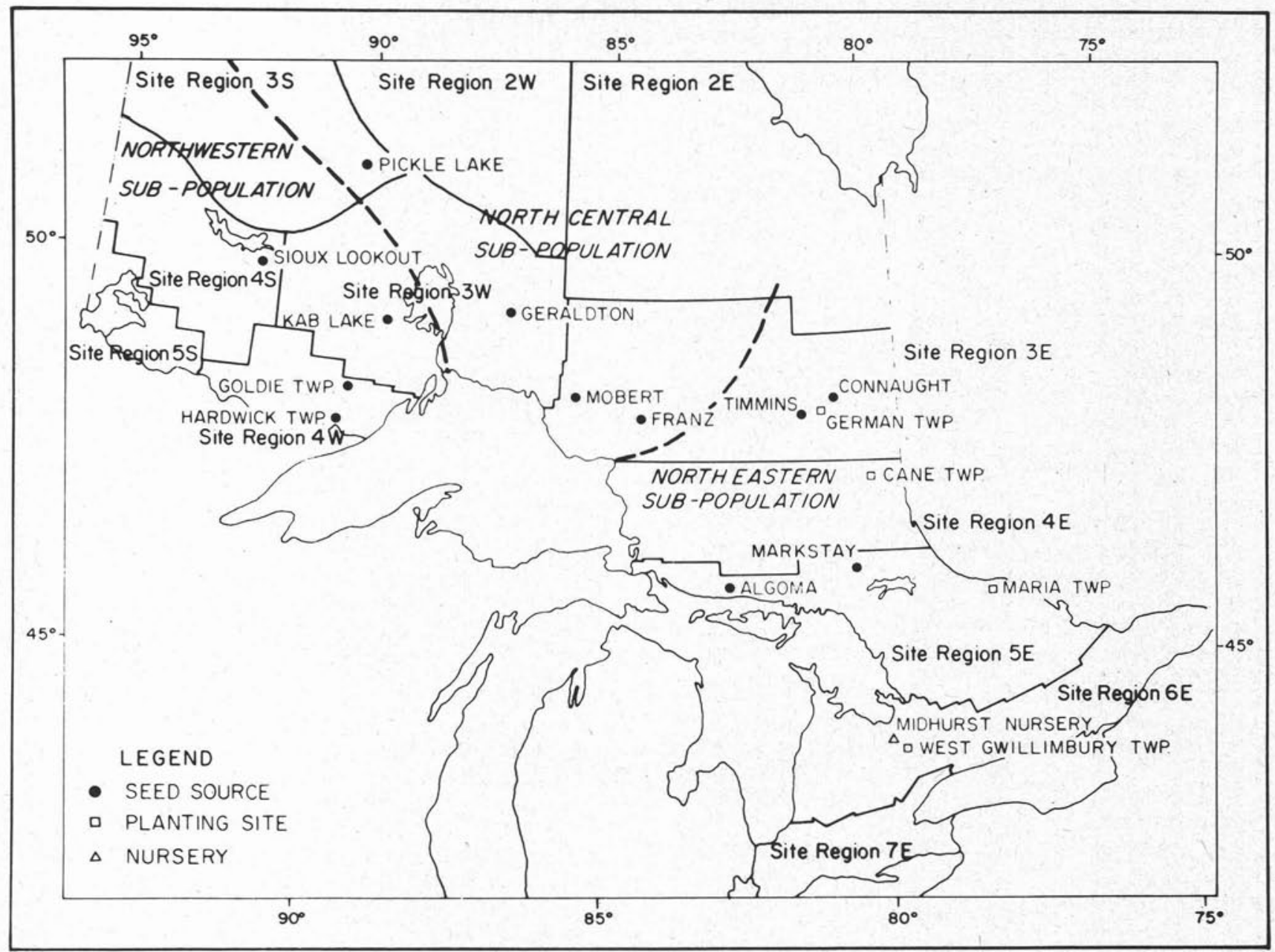

Fig. 1. Location of seed sources, nursery and planting sites in relation to subpopulations and Ontario site regions. 

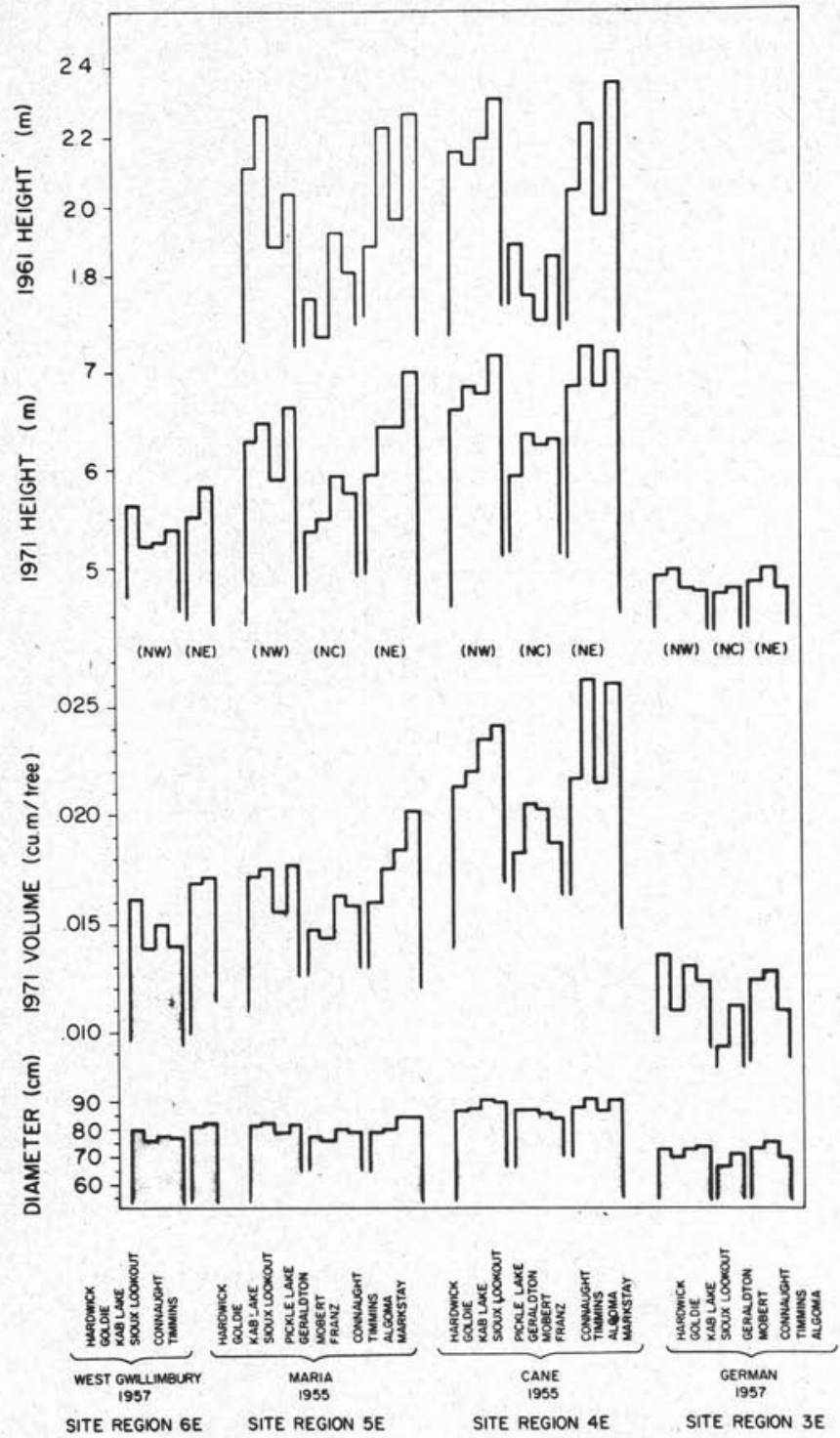

Fig. 2. Mean height, volume and diameter of jack pine seed sources growing at four experimental locations, grouped into three regions as indicated in Fig. 1. according to the formula $Y=13.09+9.34 X$, where $Y$ is the mean height at 20 years and $X$ is degree days (Boughner and Kendall 1959). This accounted for less than half the total variability $\left(r^{2}=0.486\right)$, similar to the $55 \%$ of variation found by Yeatman (1974) associated with growing degree days.

In addition to the subpopulation differentiation, trees of geographically close origins within each group exhibited consistent growth differences. Timmins trees were $6 \%$ taller than those from Connaught, $40 \mathrm{~km}$ away. Markstay trees were $7 \%$ taller than those from Algoma in the same site region. West of Lake Nipigon, trees of the more northerly Sioux Lookout source outperformed those from Kab Lake by $8 \%$ in height.

At each of the four planting sites, trees from the closest source were among the tallest. However in most of the experiments the "local" source was far removed from the experimental location. In German Township trees of Timmins origin were tallest, but those of Connaught $40 \mathrm{~km}$ east of Timmins were shorter than trees of such distant origin as Sioux Lookout. In Cane Township the tallest trees were from Timmins seed $125 \mathrm{~km}$ northwest and Markstay $125 \mathrm{~km}$ south. In Maria Township the tallest trees were from Markstay, $200 \mathrm{~km}$ west. In West Gwillimbury the tallest trees were from Timmins, about $500 \mathrm{~km}$ north and again Sioux Lookout trees outperformed those from Connaught near Timmins.

\section{Discussion and Conclusions}

This series of experiments provides some indication of the variation within the jack pine population in Ontario. Some of the variation can be explained by the clinal adaptation to growing conditions from south to north; some can be attributed to regional variation; and some to stand variation within regions.

\section{Growth Related to Growing Seasons}

In the two major trials, height growth was positively correlated with length of growing season expressed as growing degree days at seed origin, which confirms conclusions by Schantz-Hansen and Jensen (1952), Stoeckler and Rudolph (1956), Holst and Yeatman (1961) Holst (1964) and Yeatman (1974). Though this analysis accounted for close to half the observed variation in provenance height, trees of some northern sources, notably Sioux Lookout and Timmins, grew relatively taller than would be expected considering their

\begin{tabular}{|c|c|c|c|c|c|c|c|}
\hline $5.8 \mathrm{~m}$ & $6.0 \mathrm{~m}$ & $6.2 \mathrm{~m}$ & $6.4 \mathrm{~m}$ & & & $7.0 \mathrm{~m}$ & \\
\hline & & & & & 1 & 1 & \\
\hline \multirow[t]{2}{*}{$\begin{array}{l}\text { PICKLE LAKE } \\
\text { (NC) }\end{array}$} & $\begin{array}{l}\text { GERALDTON } \\
\text { (NC) }\end{array}$ & $\begin{array}{l}\text { MOBERT } \\
\text { (NC) }\end{array}$ & $\begin{array}{l}\text { KAB LAKE } \\
\text { (NW) }\end{array}$ & $\begin{array}{l}\text { HARDWICK } \\
\text { (NW) }\end{array}$ & $\begin{array}{l}\text { GOLDIE } \\
\text { (NW) }\end{array}$ & $\begin{array}{c}\text { SIOUX LOOKOUT } \\
\text { (NW) }\end{array}$ & $\begin{array}{l}\text { MARKSTAY } \\
\text { (NE) }\end{array}$ \\
\hline & \multicolumn{2}{|c|}{$\begin{array}{l}\text { FRANZ } \\
\text { (NC) }\end{array}$} & \multicolumn{2}{|c|}{$\begin{array}{l}\text { CONNAUGHT } \\
\text { (NE) }\end{array}$} & $\begin{array}{l}\text { OMA } \\
\text { E) }\end{array}$ & $\begin{array}{l}\text { MINS } \\
\text { NE) }\end{array}$ & \\
\hline
\end{tabular}

$\mathrm{NC}, \mathrm{NW}, \mathrm{NE}$ - North central, Northwestern, Northeastern subpopulations as illustrated in Figure 1.

Lines connect seed sources between which there is no significant height differences using Q-value calculations (Table A-15, Snedecor and Cochran, 1967).

Fig. 3. Comparison of mean height performance based on seed origin. 
latitude of origin. This supports Yeatman's (1974) results at Petawawa Forest Experiment Station in which many of the same seed lots as in the study reported here were used.

\section{Growth Related to Population Evolution and Migration}

Population variation related to geographic origin must take into account evolution and migration history (Yeatman 1967). The clinal pattern found in this study is consistent with migratory evidence. The results of the oldest Lake States trials suggested ". ... the existence of geographic races of jack pine that have very distinct growth characteristics" (Schantz-Hansen and Jensen 1952). A later study by King (1966) in which seedlings from 26 Lake States sources were planted in 17 experiments in Minnesota, Michigan and Wisconsin indicated significant discontinuous geographic variation of jack pine stands, i.e. different genetic development in the separated areas of the Lake States. Differentiation between subpopulations was most strongly expressed on especially favourable or unfavourable sites.

It is reasonable to expect similar population differentiation across Ontario considering the discontinuity of jack pine stands. Despite the sparse sampling in this study, there is an apparent geographic grouping indicating independent development of at least the north-central group consisting of the Pickle Lake, Geralidton, Franz and Mobert sources. These appear to form a subpopulation with a low growth potential compared with most sources from either east or west. This is supported by the relatively poor performance of the Stevens source in the Petawawa experiment (Yeatman 1974) and the Caramat and Terrace Bay sources from the same north-central subpopulation in the all range jack pine study (Yeatman, personal communication) ${ }^{2}$ established in 1966 (Holst 1967). In a seedling growth study (Giertych and Farrar 1962) the Stevens source exhibited slower growth than the other Ontario sources.

Yeatman (1967) showed that jack pine survived glaciation in an extensive refugium in the Appalachian highlands. The species then migrated westerly along the shores and former beachlines of the glacial lakes south of the present Great Lakes as climatic conditions moderated. McAndrews (1973) has identified jack pine pollen in southern Ontario lake bottom sediments between 10000 and 9500 years ago, about the same time period thiat the species occurred in the Minneapolis area. One branch of the migration reached northwestern Ontario from south of Lake Superior, and a second branch apparently moved into the north through southern Ontario.

It is quite likely that the jack pine population in Ontario differentiated on an altitudinal basis. The easiest migration channel, north through the Ottawa Valley towards Cane Township would have encountered generally low elevations. Migrations westerly and northwesterly towards Franz and Mobert and beyond would have encountered the greatest hurdle in the high elevations around Lake Superior toward the sand plains of Geraldton (Hills 1962). High elevations would accentuate the adverse growing conditions of the post glacial period and likely affect selection for frost hardy varieties adapted to short growing seasons. The population of jack pine north and west of this area towards Geraldton and Pickle Lake would therefore have been characterized by relatively slow growth. Lake Nipigon formed a barrier to westerly development of this population.

As climate moderated, population adaptation would be expected to follow. However, movement of pollen from the west was, and still is, restricted by Lake Nipigon, while westerly movement of pollen or seed from the faster grow-

2Unpublished 10-year data from Experiment 255, Petawawa Forest Experiment Station. ing eastern sources is hampered by adverse prevailing winds and discontinuity in occurrence of jack pine stands.

In many species, growth rate is negatively correlated to elevation at point of seed origin. In a species such as jack pine, still adapting to changing climatic conditions, growth potential is probably affected by the elevations encountered on its migratory route.

\section{Growth Related to Stand Variation Within Subpopulations}

Variations in growth potential betweeen sources in the same region illustrate the importance of stand selection and testing for seed production. Trees grown from Timmins seed outperformed those from Connaught in the four trials. Despite proximity of the two sources (40 km apart) differences in performance suggest genetic differences between seed sources as a result of response to local climatic and site conditions. Gains in height of 5 to $10 \%$ appear possible through stand selection and testing within regions. Height gains of this magnitude are likely to provide volume gains of up to $20 \%$ (Ottens and Carlisle 1976). As indicated by Yeatman and Teich (1969) there are needs for designating and testing seed collection areas, close supervision of all cone collections and the maintenance of identity of seed sources.

\section{Recommendations for Action in Ontario}

The results of this study indicate that gains in early height growth are possible by skilful use of provenance knowledge. There is an urgent need to achieve the potential improvements suggested by these data. For the immediate future areas requiring artificial regeneration should be seeded or planted using apparently good quality local seed origins. Distribution of seed to adjacent seed zones north and south or even within the very large seed zones based on Hills (1960) site regions could result in losses due to frost damage and disease susceptibility. Recent modifications of the Ontario seed zones (Skeates 1979) with the intent of distributing seed within the administrative district of collection should help to minimize such potential losses.

Regional provenance testing is urgently required to delineate major subpopulations more accurately. These should include all selected seed collection areas so as to identify seed sources with potentially fast-growing progeny. From these tests it will be possible to determine how potentially valuable seed sources might safely be utilized to society's benefit in future seed transfer rules.

Informed seed transfer will only be possible when the origins of seed collections are adequately identified. Supervision of collections will be necessary to ensure proper identification of seed lots.

In addition to long-term research, it is possible for field staff to develop local experience through test plantings of various sources. Comparison plantings of local sources with some of the apparently better sources indicated by these data would contribute to the accumulation of knowledge. This is particularly important in districts within the northcentral population east of Lake Nipigon, identified here as having relatively poor growth potential.

Implementation of these recommendations will ensure a minimum in potential growth loss in current regeneration programs as well as a build up in knowledge of population structure. Utilization of such knowledge in future seed policies should contribute to the gains in productivity per hectare suggested in this study.

\section{Acknowledgements}

The author wishes to acknowledge the early efforts of A. J. Carmichael in establishment of the four reported experiments and the 1961 assessment of two of these. Mr. G. Suranyi and Professor D. 
B. W. Reid assisted in analyses of pooled data on which conclusions have been based. Valuable critical reviews were provided by Dr. A. H. Teich and Dr. C. W. Yeatman of the Canadian Forestry Service, Petawawa Forest Experiment Station, Dr. D. Burger, Ontario Forest Research Centre, Ontario Ministry of Natural Resources, and Professor D. B. W. Reid of the University of Toronto.

Draughting and reproduction of illustrations was completed by $\mathrm{J}$. Hall and Miss J. Robinson respectively.

\section{References}

Boughner, C. C., and Kendall, G. R. 1959. Growing degree-days in Canada. Can. Dep. Transport, Meteorol. Br. Circ. 3203.

Carmichael, A. J. 1962. Report to Committee on Forest Tree Breeding. In Proc. Eighth Meeting Comm. Forest Tree Breeding Can.

Giertych, M. M., and Farrar, J. L. 1962. A provenance study of jack pine seedlings. Silvae Genet. 11: 111-114.

Hills, G. A. 1960. Regional site research. For. Chron. 36: 401-423.

Hills, G. A. 1962. Soil-vegetation relationships in the boreal clay belts of eastern Canada. p. 39-53. In Baldwin, W. K. W. Report on Botanical excursion to the boreal region in Northern Québec and Ontario. Can. Dep. Nor. Affairs and Natur. Res. Canada.

Holst, M. J. 1964. Forest tree breeding and genetics at the Petawawa Forest Experiment Station, p. 63-107. In Proc. Ninth Meeting Comm. Forest Tree Breeding Can.

Holst, M. J. 1967. All-range jack pine provenance experiment. Can. For. Serv. Petawawa Forest Experiment Station. Internal Report PET.PS-6.
Holst, M. J., and Yeatman, C. W. 1961. A provenance study in Pinus banksiana Lamb. Recent Advances in Botany. 1612-1616.

Honer, T. G. 1967. Standard volume tables and merchantable conversion factors for the commercial tree species of central and eastern Canada. Can. For. Man. Res. and Services Inst., Interim Rep. FMR-S-5.

King, J. P. 1966. Ten year height growth variation in Lake States jack pine. U.S. For. Serv. Res. Paper NC-6, 84-88.

McAndrews, J. H. 1973. Pollen analyses of the sediments of the Great Lakes of North America. p. 76-80. In Proc. III Int. Palynological Conf.

Ottens, J., and Carlisle, A. 1976. Tree improvement does pay. Pulp and Paper (Canada) Aug. Issue.

Schantz-Hansen, T., and Jensen, R. A. 1952. The effect of seed on growth of jack pine. J. For. 50: 539-544.

Skeates, D. A. 1979. Seed registration in Ontario, an historical review and a look toward the future p. 168-180. In COJFRC Symposium Proceedings, 0-P.7. Tree Improvement Symposium. Can. For. Serv., Great Lakes Forest Experiment Centre.

Snedecor, G. W., and Cochran, W. G. 1967. Statistical methods. lowa State Univ. Press.

Stoeckler, J. H., and Rudolf, P. O. 1956. Winter coloration and growth of jack pine in the nursery as affected by seed source. $Z$. Forstgenet. Forstpfl-Zucht. 5: 161-165.

Yeatman, C. W. 1967. Biogeography of jack pine. Can. J. Bot. 45: 2201-2211.

Yeatman, C. W. 1974. The jack pine genetics program at Petawawa Forest Experiment Station, 1950-1970. Can. For. Serv., Publ. 1331.

Yeatman, C. W., and Teich, A. H. 1969. Genetics and breeding of jack pine and lodgepole pines in Canada. For. Chron. 45: 428-433.

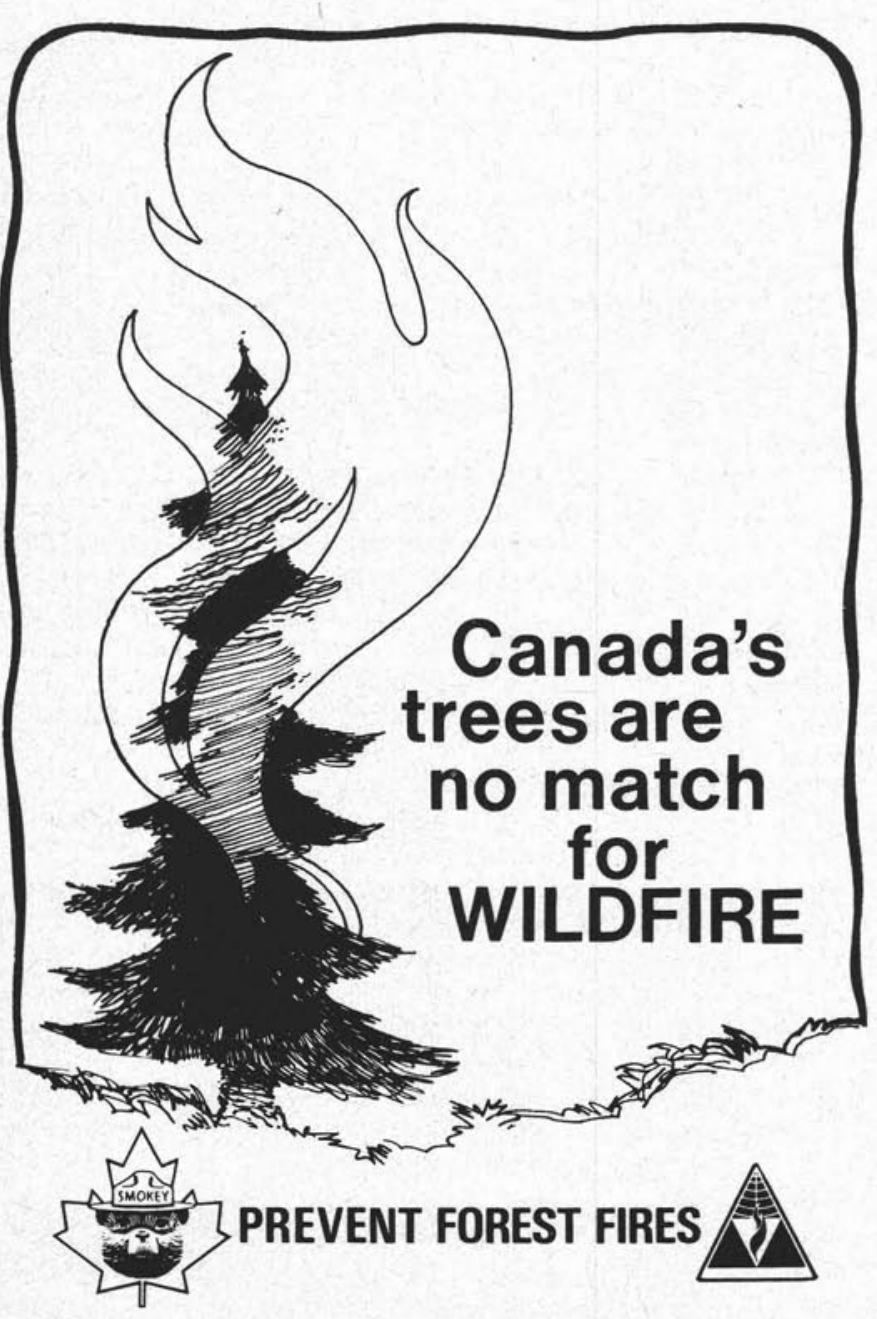

$\mathbf{k b m}$ FORESTRY CONSUITANTS INC.

360 MOONEY STREET THUNDER BAY, ONTARIO

P7B 5R4

TEL.: $344-0811$

RESOURCE INVENTORY -
FOREST MANAGEMENT PLANNING

SILVICULTURAL SPECIALISTS SYSTEM DESIGN AND CONTRACT

\section{Woodlot Service (1978) Ltd.}

"All Matters Pertaining to Forestry"

GORDON B. YOUNG, B.Sc.F., M.F.

Registered Professional Forester

320 Maple Street

Bus.: $506-472-3396$

Fredericton, N.B.

Home: 506 - 472-7721 